атрофического кольпита./ Саркисян О.Г., Микашинович 3.И., Криволапова Э.Г. //Кубанский научный медицинский вестник. 2015. № 4(153). C. 114-119

3. Evan S. E. Early effect of fractional $\mathrm{CO}_{2}$-laser treatment in postmenopausal women with vaginal atrophy Laser Ther. 2018; 27(1):41-47. doi:10.5978/islsm.18-OR-04

4. C. Knight, V. Logan' D. Fenlon A systematic review of laser therapy for vulvovaginal atrophy/genitourinary syndrome of menopause in breast cancer survivors // ecancer 2019.13:988; www.ecancer.org; DOI: https://doi.org/10.3332/ecancer.2019.988

DOI https://doi.org/10.30525/978-9934-588-81-5-1.41

\title{
КОМПЛЕКСНА ОЦІНКА ЦИРКАДІАННОЇ СТРУКТУРИ ТА НИРКОВОЇ РЕГУЛЯЦЇ̈ АТ У ЛІКУВАЛЬННІ ХВОРИХ НА ЕГ ІІ СТАДІЇ
}

\author{
Плеш І. А. \\ доктор медичних наук, професор, \\ завідувач кафедри догляду за хворими та вищої медсестринської освіти \\ ВДНЗ Украӥни «Буковинський державний медичний університет»
}

Борейко Л. Д.

кандидат медичних наук, дочент,

доиент кафедри догляду за хворими та вищої медсестринської освіти

ВДНЗ Украӥни «Буковинський державний медичний університет»

\section{Сливка Н. О.}

кандидат медичних наук,

доцент кафедри догляду за хворими та вищої медсестринської освіти

ВДНЗ Украӥни «Буковинський державний медичний університет»

Каратєева С. Ю.

кандидат медичних наук, дочент,

доиент кафедри догляду за хворими та вищої медсестринської освіти

ВДНЗ Украйни «Буковинський державний медичний університет»

Кшановська Г. I.

асистент кафедри догляду за хворими та вищої медсестринської освіти

ВДНЗ Украйни «Буковинський державний медичний університет» м. Чернівиі, Україна

Сучасне антигіпертензивне лікування хворих на есенційну гіпертензію (ЕГ) ІІ стадії можливе за умови встановлення основних механі146 
змів стабілізації та програмування ЕГ. Досягнення такої мети дозволить не тільки патогенетично обгрунтовано призначати фармакологічні препарати, але й контролювати їх ефективну дозу, уникнути побічних явищ терапії і цим самим покращити прихильність до лікування. $[1$, c. $38 ; 2$, с. $18 ; 4$, c. 81$]$.

Ще більше актуальною постає ця проблема за необхідності постійного контрольованого, тривалого АГ-лікування [1, с. 35; 6, с. 19; 10 , c. $30-46]$.

Тому метою нашого дослідження є спроба адаптувати основні клінічно-діагностичні показники:судинний тонус та волемічний компоненти для потреб лікувальної практики.

Нами комплексно обстежені 65 хворих на ЕГ II ст. (BOO3, 2013) середнього віку $(53,2 \pm 2,44$ роки), переважно чоловічої статі $(68 \%)$.

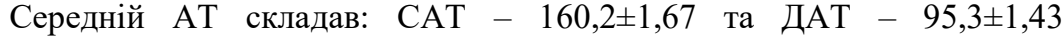
(мм рт.ст.). Проводили визначення показників добового моніторування АТ (ДМАТ): середньодобової величини АТ (середньоденні та нічні), середньодобовий середній динамічний АТ (СДТ), визначали варіант циркадіанної структури АТ - добовий індекс (ДІ). Вивчали волемічну складову АТ за величиною добового діурезу та натрійурезу.

Дослідження добової структури АТ проводили на апаратному комплексі «Solvaig» (Україна) за загальновизнаною методикою (кожні 15 хв в активний та 30 хв в пасивний періоди доби), за критерієм успішності вище $80 \%$. Іонний склад добового діурезу проведено з використанням іонселективних електродів на апараті (SINO-005) (КHР). Дослідження проведено на 2-3 день перебування в стаціонарі та через 7-10 днів стаціонарного лікування.

За результатами дослідження серед 65 хворих на ЕГ ІІ ст. 26 (40\%) - мали циркадіанний ритм «Dipper»; 31 (48\%) - «Non dipper» та 8 (12\%) - «Night picker». Отже, серед обстежених хворих на ЕГ II ст. 3 тривалим гіпертензивним анамнезом (>8-10 років) переважали «не діппери» $-60 \%$.

Основні величини добової структури АТ за добовим індексом представлені в таб. 1.

\begin{tabular}{|c|c|c|c|c|c|c|c|}
\hline $\begin{array}{c}\text { Групи } \\
\text { хворих }\end{array}$ & $\begin{array}{c}\text { ССАТ доб. } \\
\text { мм рт.ст. }\end{array}$ & $\begin{array}{c}\text { ССАТ } \\
\text { після мм } \\
\text { рт.ст. }\end{array}$ & $\begin{array}{c}\text { СДАТ } \\
\text { доб. мм } \\
\text { рт.ст. }\end{array}$ & $\begin{array}{c}\text { СДАТ } \\
\text { після } \\
\text { мм рт.ст. }\end{array}$ & $\begin{array}{c}\text { СДТ доб. } \\
\text { мм рт.ст. }\end{array}$ & $\begin{array}{c}\text { СДТ після } \\
\text { мм рт.ст. }\end{array}$ & ДІ \% \\
\hline $\mathrm{D}(\mathrm{n}=26)$ & $137,6 \pm 2,42$ & $135,3 \pm 2,21$ & $87,2 \pm 1,53$ & $86,1 \pm 1,32$ & $104,2 \pm 0,56$ & $103,8 \pm 0,39$ & $13,7 \pm 1,21$ \\
\hline $\begin{array}{c}\mathrm{ND} \\
\mathrm{n}=31)\end{array}$ & $144,2 \pm 2,21^{*}$ & $140,1 \pm 2,08$ & $94,2 \pm 1,63 *$ & $91,3 \pm 1,39$ & $109,9 \pm 0,38^{*}$ & $106,2 \pm 0,41$ & $8,1 \pm 0,92$ \\
\hline $\mathrm{NP}(\mathrm{n}=8)$ & $145,7 \pm 2,76^{*}$ & $139,8 \pm 2,01$ & $98,8 \pm 1,71 *$ & $91,8 \pm 1,67$ & $116,8 \pm 0,79 *$ & $106,9 \pm 0,38$ & $-2,2 \pm 0,39$ \\
\hline
\end{tabular}


3 представлених в таб. 1 даних в межах однієї стадії захворювання розподіл за циркадіанною структурою виявив суттєві відмінності .

Вірогідно вищий CCAT та СДАТ за добу у групах ND та NP. Інтегральна величина АТ-СДТ була в зворотній залежності від величини ДІ. Після 7-10 денного комплексного лікування 3 використанням діуретиків більш ефективно знизився ССАТ та СДАТ у хворих груп ND та NP.

Відомо, що рівень АТ обумовлений не тільки тонусом стінки артеріальних судин, але й величиною наповнення кров'ю судинного русла, яке чітко контролюється нирками за фізіологічним механізмом «тиск-натрійурез» або «пресорний натрійурез» [3, с. 67; 5, с. 224; 7 , c. $35 ; 8$, c. 49$]$.

Дані основних величин ниркової волюморегуляції у хворих на ЕГ II ст. 3 циркадіанними ритмами представлені в таб. 2

\begin{tabular}{|c|c|c|c|c|c|c|c|c|}
\hline & $\begin{array}{c}\text { Доб. } \\
\text { діурез } \\
\text { мл. }\end{array}$ & $\begin{array}{c}\text { Доб. } \\
\text { після }\end{array}$ & $\begin{array}{c}\mathrm{E} \mathrm{Na} \\
\text { доб. }\end{array}$ & $\begin{array}{c}\mathrm{E} \mathrm{Na} \\
\text { Після }\end{array}$ & $\begin{array}{c}\Delta \text { Д. } \\
\text { мл. }\end{array}$ & $\begin{array}{c}\Delta \mathrm{E} \mathrm{Na} \\
\text { ммоль }\end{array}$ & $\begin{array}{c}\text { КПН } \\
\text { до }\end{array}$ & $\begin{array}{c}\text { КПН } \\
\text { після }\end{array}$ \\
\hline $\mathrm{D}(\mathrm{n}=26)$ & $1421 \pm 367$ & $1482 \pm 343$ & $172 \pm 3,21$ & $178 \pm 2,47$ & +61 & $+6(+3,5 \%)$ & $1,69 \pm 0,18$ & $1,78 \pm 0,12$ \\
\hline $\begin{array}{c}\mathrm{ND} \\
\mathrm{n}=31)\end{array}$ & $1362 \pm 286$ & $1482 \pm 301$ & $158 \pm 2,98$ & $173 \pm 2,73 *$ & +66 & $+15(+10,9 \%)$ & $1,39 \pm 0,10$ & $1,56 \pm 0,11$ \\
\hline $\mathrm{NP}(\mathrm{n}=8)$ & $1357 \pm 321$ & $1440 \pm 315^{*}$ & $157 \pm 3,43$ & $175 \pm 3,08^{*}$ & +73 & $+18(+11,2 \%)$ & $1,36 \pm 0,12$ & $1,52 \pm 0,12$ \\
\hline
\end{tabular}

3 представлених даних після поступлення в стаціонар у хворих 3 циркадіанним ритмом ND та NP виявлено тенденцію до зниження добового діурезу та вірогідно нижчі величини добового натрійурезу.

Після 7-10 денної корекції АГ-терапії з включенням комбінованих препаратів I класу поєднаних з салуретичними (діуретичними) препаратами (гідрохлортіазиду) 25-50мг за добу середні величини діурезу та натрійурезу вірогідно зросли у хворих ND та NP при умові дотримання дієтичного харчування (стіл №10). Дещо знизився рівень середніх величин АТ за даним ДМАТ (таб.1), що вказує: по-перше, на суттєву роль волемічного компоненту у генезі циркадіанних ритмів AT - ND та NP; по-друге, про високу ефективність і патогенетично обгрунтоване у них застосування комбінованої терапії з обов'язковим діуретичним компонентом; по-третє, дає можливість контролювати дозу салуретичного препарату та нормалізувати у них механізм «пресорного натрійурезу» з оптимальним використанням дози діуретика за коефіцієнтом пресорного натрійурезу (КПН = 1,5-2,0), що може попередити побічні дії цих препаратів. [10, с.21] 
Таким чином, контрольована корекція механізму «пресорного натрійурезу» може бути рекомендована у клінічній практиці як варіант патогенетично обгрунтованої оптимальної антигіпертензивної терапії.

\section{Література:}

1. Сіренко Ю.М., Міщенко Л.А., Єна Л.М. та ін. Класифікація та стандарти надання медичної допомоги хворим на артеріальну гіпертензію. Асоціація кардіологів України. Проект . Артериальная гипертензия. 2018. № 4 (60). С. 32-53.

2. Бильченко А.В. Новое в диагностике и контроле лечения артериальной гипертензии. Therapia. 2016. № 10. С. 17-20.

3. Бобров В. А., Боброва Е. В., Перепельченко Н.А., Давыдова И.В., Медведенко О.И. Место диуретиков в лечении артериальной гипертензии: пора расставить приоритеты. Украӥнсткий медичний часопис. 2011. № 5. С. 65-70.

4. Долженко М.Н., Шершнева О.П. Комбинированая антигипертензивная терапия. Политаблетка - будуще фармакологи. Украӥнсткий медичний часопис. 2014. № 5. С. 81-82.

5. Зелтынь-Абрамов Е.М. Фролова Н.Ф. Артериальная гипертензия при ХБП: от начальных до продвинутых стадий. Диагностические и терапевтические стратегии. Часть 1. Артериальная гипертензия у пациентов с ХБП 1-4 стадий. Нефрология и диализ. 2020. № 22(2). C. 221-236.

6. Лутай М.І. Ефективність комбінованої терапії артеріальної гіпертензії в Україні: результати багатоцентрового дослідження ТРІУМФ. Украӥнський кардіологічний журнал. 2016. № 4. С. 17-27.

7. Матюха Л.Ф. Застосування діуретиків у пацієнтів із артеріальною гіпертензією: перспективи й обмеження. Украйнсткий медичний часопис. 2016. № 2 (112). С. 33-36

8. Міщенко Л.А. Предиктори погіршення функціонального стану нирок у хворих на гіпертонічну хворобу. Украӥнський кардіологічний журнанал 2015. № 4. С. 47-52.

9. Спосіб лікування хворих на есенційну гіпертензію / I.А. Плеш, Л.П. Сидорчук // Патент на корисну модель № 108985. Бюл. № 15 від 10.08.2016.

10. Williams B., Mancia G., Spiering W. et al. 2018 ESC/ESH Guidelines for the management of arterial hypertension. 2018. Vol. 39 (33) P. 3021-3104. 